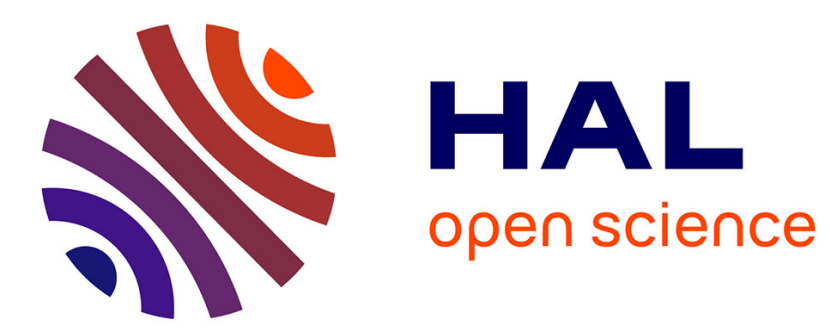

\title{
Geomorphologic and paleoclimatic evidence of Holocene glaciation on Mount Olympus, Greece
}

Michael Nikolaos Styllas, Irene Schimmelpfennig, Matthieu Ghilardi, Lucilla

Benedetti

\section{- To cite this version:}

Michael Nikolaos Styllas, Irene Schimmelpfennig, Matthieu Ghilardi, Lucilla Benedetti. Geomorphologic and paleoclimatic evidence of Holocene glaciation on Mount Olympus, Greece. The Holocene, 2016, 26 (5), pp.709-721. 10.1177/0959683615618259 . hal-01469876

\section{HAL Id: hal-01469876 \\ https://hal-amu.archives-ouvertes.fr/hal-01469876}

Submitted on 24 Feb 2017

HAL is a multi-disciplinary open access archive for the deposit and dissemination of scientific research documents, whether they are published or not. The documents may come from teaching and research institutions in France or abroad, or from public or private research centers.
L'archive ouverte pluridisciplinaire HAL, est destinée au dépôt et à la diffusion de documents scientifiques de niveau recherche, publiés ou non, émanant des établissements d'enseignement et de recherche français ou étrangers, des laboratoires publics ou privés. 


\title{
Geomorphologic and paleoclimatic evidence of Holocene glaciation on Mount Olympus, Greece
}

\author{
Michael Nikolaos Styllas,' Irene Schimmelpfennig, ${ }^{2}$ \\ Matthieu Ghilardi² and Lucilla Benedetti²
}

\begin{abstract}
This study investigates the possibility of Holocene glaciation on Mount Olympus (Greece) with a respective local temperature-precipitation equilibrium line altitude (TP-ELA) at c. $2200 \mathrm{~m}$ a.s.l., based on geomorphologic and paleoclimatic evidence. At present, the local TP-ELA is situated above the mountain's summit (c. $2918 \mathrm{~m}$ a.s.l.), but permanent snowfields and ice bodies survive within Megala Kazania cirque between c. 2400 and c. $2300 \mathrm{~m}$ a.s.l., because of the cirque's maritime setting that results from its close proximity $(c$. $18 \mathrm{~km})$ to the Aegean Sea and of the local topographical controls. The snow and ice bodies occupied a considerably larger area and attained a stabilization phase between AD 1960 and 1980, also manifested from aerial photographs, a period characterized by increased winter precipitation $\left(P_{w}\right)$ with subsequent TP-ELA depression to c. $2410 \mathrm{~m}$ a.s.l. Mid- to late-20thcentury $P_{w}$ and TP-ELA variations exhibit negative correlations with the winter North Atlantic Oscillation index $\left(\mathrm{NAO}_{\mathrm{w}}\right)$ at annual and multidecadal (30years) timescales. Late Holocene (AD 1680-1860) reconstructed summer mean temperatures were lower by $T_{s}<1.1^{\circ} \mathrm{C}$ in relation to the reference period between AD 1960 and 1980 and were also superimposed to negative $\mathrm{NAO}_{w}$ phases, thus bracketing this time interval as a favorable one to glacial formation and/or advance. Millennial-scale annual precipitation reconstructions at the hypothesized TP-ELA (c. $2200 \mathrm{~m}$ a.s.l.) point the period between 8 and $4 \mathrm{kyr} \mathrm{BP}$ as another glacier-friendly candidate. The mid-Holocene rather simplistic sequence of potential glacial advance phase was disturbed by short-lived cold climatic deteriorations, well-documented over the northern Aegean region that may partly explain the multicrested shape of the highest (c. $2200 \mathrm{~m}$ a.s.l.) morainic complex of Megala Kazania cirque.
\end{abstract}

\section{Keywords}

climate, Holocene, Mount Olympus, North Atlantic Oscillation, permanent snowfields and ice bodies, temperature-precipitation equilibrium line altitude

Received 22 June 2015; revised manuscript accepted 24 September 2015

\section{Introduction}

The Holocene glacial history of Balkan peninsula, the 'European biodiversity hotspot' (Griffiths et al., 2004), has received considerably less attention in relation to northern (e.g. Norway, Sweden), central (e.g. Alps), and southern (e.g. Pyrenees, Apennines) parts of Europe. The number of studies referring to Lateglacial and Holocene glacial evolution of Balkans has grown only recently as published research has dealt with glacial landforms and sediments from mountains of Montenegro (e.g. Hughes, 2008, 2010; Hughes et al., 2011), Bulgaria (e.g. Grunewald and Scheithauer, 2010), FYROM (e.g. Kuhlemann et al., 2009), and Albania (e.g. Milivojevič et al., 2008; Wilkinson, 2011).

Greece occupies the southern part of Balkan peninsula. Climate attains Mediterranean status in contrast to more temperate conditions that occur further north, but like the rest of Balkans, Greek mountains have been glaciated several times in the past (e.g. Hughes et al., 2007; Smith et al., 2006). Early accounts of Pleistocene glaciation were devoted to general descriptions of glacial and periglacial features of mountains along central and northern Greece (references within Smith et al., 1997). These pioneering studies were followed by conclusive research that included accounts of the Pleistocene glacial history of Mount
Olympus and Pindos Range respectively. On Mount Olympus, investigations focused on the spatial extent of glacial sediments and temporal variations of Equilibrium Line Altitude (ELA) (Smith et al., 1997, 2006). In Pindos Range, positioned west of Mount Olympus, studies of glacial, periglacial, and glaciofluvial stratigraphy, complemented with radiometric dating, resulted in detailed chronostratigraphy and ELA reconstructions spanning Middle and late Pleistocene (Hughes et al., 2003, 2006, 2007).

Among the later studies, conflicting opinions concerning the culmination of the last glaciation in Greece exist. A review study that focused on terminal moraine elevations and ELA approximations for Tymphi and Smolikas Mountains, along the northern extent of Pindos Range (locations in Figure 1), has excluded the potential of Holocene glaciation in Greece, further postulating that

'Geoservice Ltd, Greece

${ }^{2}$ Cerege, France

\section{Corresponding author:}

Michael Nikolaos Styllas, Eirinis 15 Street, 55236, Panorama, Thessaloniki, Greece.

Email: mstyllas@gmail.com 

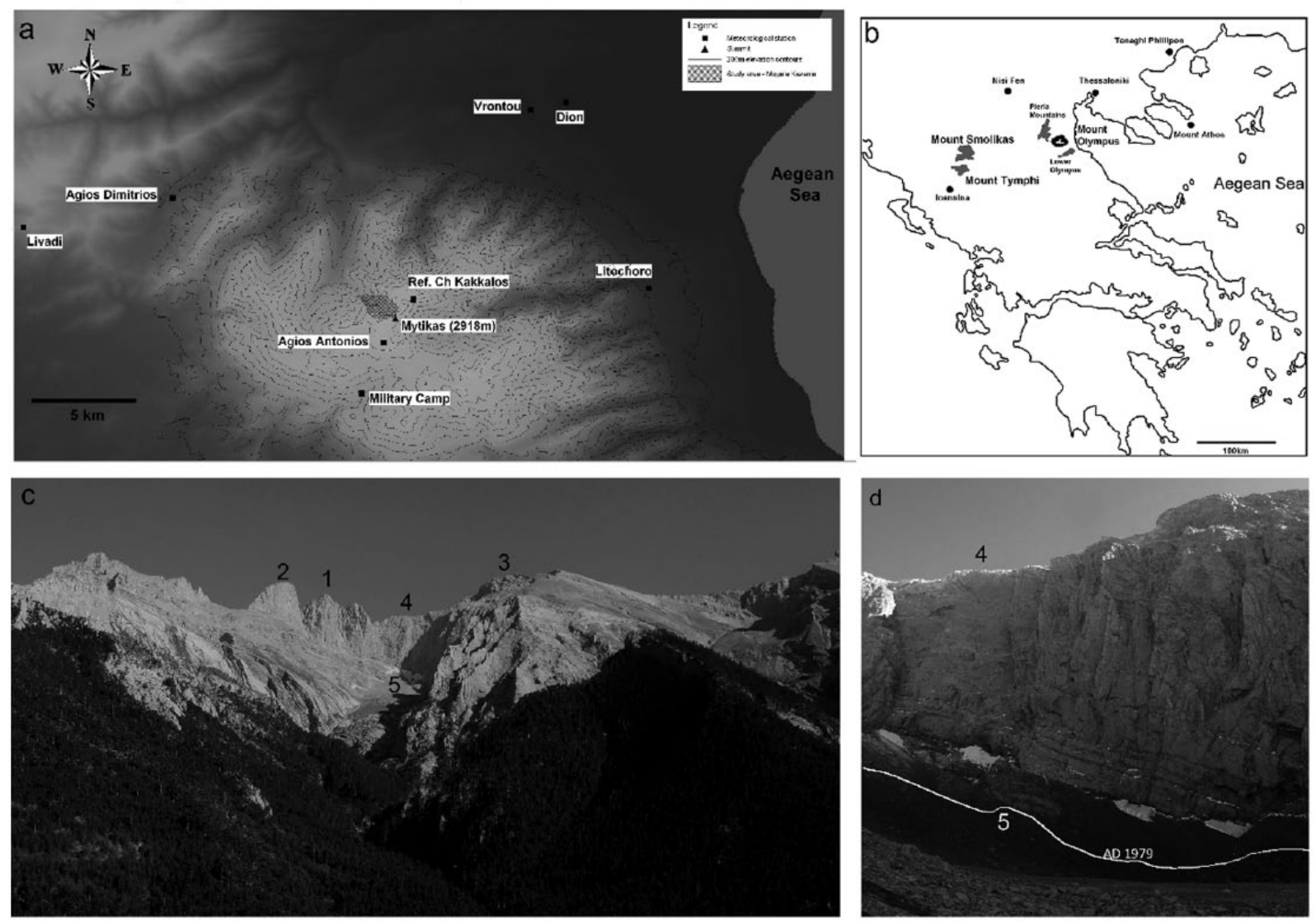

Figure I. General setting of the key features used in the study: (a) Mount Olympus topography with respective locations of the meteorological stations used in the study and location of Megala Kazania cirque, (b) geographical location of Mount Olympus in relation to important paleoclimate study sites of glacial, marine, and lacustrine sequences across northern Greece, (c) Megala Kazania valley viewed from the west with main geomorphological features I: Mytikas $2918 \mathrm{~m}$ a.s.l., 2: Stefani $2909 \mathrm{~m}$ a.s.l., 3: Skolio $2912 \mathrm{~m}$ a.s.l., $4:$ Skala $2866 \mathrm{~m}$ a.s.l., 5 : Area of recent existence of permanent snowfields and ice patches, occupied by three sets of end-moraines (a, b, and c) (photo taken on 18 August 20I3), and (d) the four persistent Mount Olympus snow and ice patches (Figures 2 and 3) under the 500-m high walls of Skolio at the end of the ablation season, surviving another mild winter and a warm summer (photo taken on I October 20I4). White line represents the approximate AD 1979 snow extent derived from an aerial photograph taken on 20 September 1979.

extinction of Greece's last glaciers was contemporary to the termination of the Younger Dryas (12.6-11.7 kyr BP) stadial (Hughes et al., 2006, 2007). This statement is contradictory to the findings of Smith et al. (1997, 2006) who tentatively argued that glacial features (moraines) within the cirque of Megala Kazania in Mount Olympus are of 'Neoglacial' age.

In this study, we show that direct observations from Mount Olympus, complemented with historical evidence, confirm the existence of permanent snow and ice patches (locally referred to as 'Mount Olympus Eternal Snows') within Megala Kazania cirque. Extant snow and ice bodies survive in niches along the base of the nearly 500-m vertical north facing rock walls bounding the cirque, at elevations between 2300 and $2400 \mathrm{~m}$ a.s.l. While currently the temperature-precipitation equilibrium line altitude (TP-ELA) is above the mountain's summit, persistent ice is debris-covered, overlain by thick layers of firn snow. Both features (permanent snowfields and ice bodies) are bounded by high lateral moraines and are products of the local topoclimatic regime (temperature, precipitation, shading, and high inputs of wind-blown and avalanching snow) enhanced by the cirque's maritime setting that results from its close proximity $(c .18 \mathrm{~km})$ to the Aegean Sea. Distanced from the glaciers and closer to the cirque floor, eroded lateral moraines, end-moraine crests, boulder ridges, and nival and fluvial landforms exist. Such evidence combined with the sensitivity of small glaciers to climatic oscillations (e.g. Brown et al., 2010; Dahl et al., 2003; Grunewald and Scheithauer, 2010) aroused further speculation whether the area of Megala Kazania had been occupied by active glacier(s), at climatic intervals favorable to glacial advance, during the Holocene. For Mount Olympus and broader northern Aegean regions, intervals when paleoclimate would have depressed the local TP-ELA to elevations below the cirque backwall and close to the cirque floor (c. $2200 \mathrm{~m}$ a.s.1.) are derived from empirical relationships utilizing meteorological data (following the approach of Lie et al., 2003) and from local and regional paleoclimate proxies (e.g. foraminifera assemblages, pollen, tree-rings, sediment properties), representing terrestrial, lacustrine, and marine settings (e.g. Francke et al., 2013; Griggs et al., 2007; Klesse et al., 2014; Kotthoff et al., 2008a, 2008b; Mauri et al., 2015; Peyron et al., 2011; Pross et al., 2009; Rohling et al., 2002; Tzedakis, 2007).

In the light of a well-established Holocene climate variability pattern for the northern Aegean region, this paper is testing the hypothesis of Holocene glaciation on Mount Olympus. The present work is based on direct geomorphological observations, meteorological data, paleoclimate prox aerial photographs, and historical accounts, in an attempt to deduce climatically favorable periods of glacier advance on Mount Olympus in reverse chronological order from the mid-late 20th century to the early Holocene.

\section{Geological setting and Pleistocene glaciations}

Mount Olympus $\left(40^{\circ} 04^{\prime} 54^{\prime \prime} \mathrm{N}, 22^{\circ} 21^{\prime} 28^{\prime \prime} \mathrm{E}\right)$ is Greece's highest mountain and second highest of Balkan peninsular. Its summit, 'Mytikas' or 'Pantheon', reaches an elevation of $2918 \mathrm{~m}$ a.s.l., located $18 \mathrm{~km}$ west of Aegean Sea shoreline (Figure 1a). Mount 


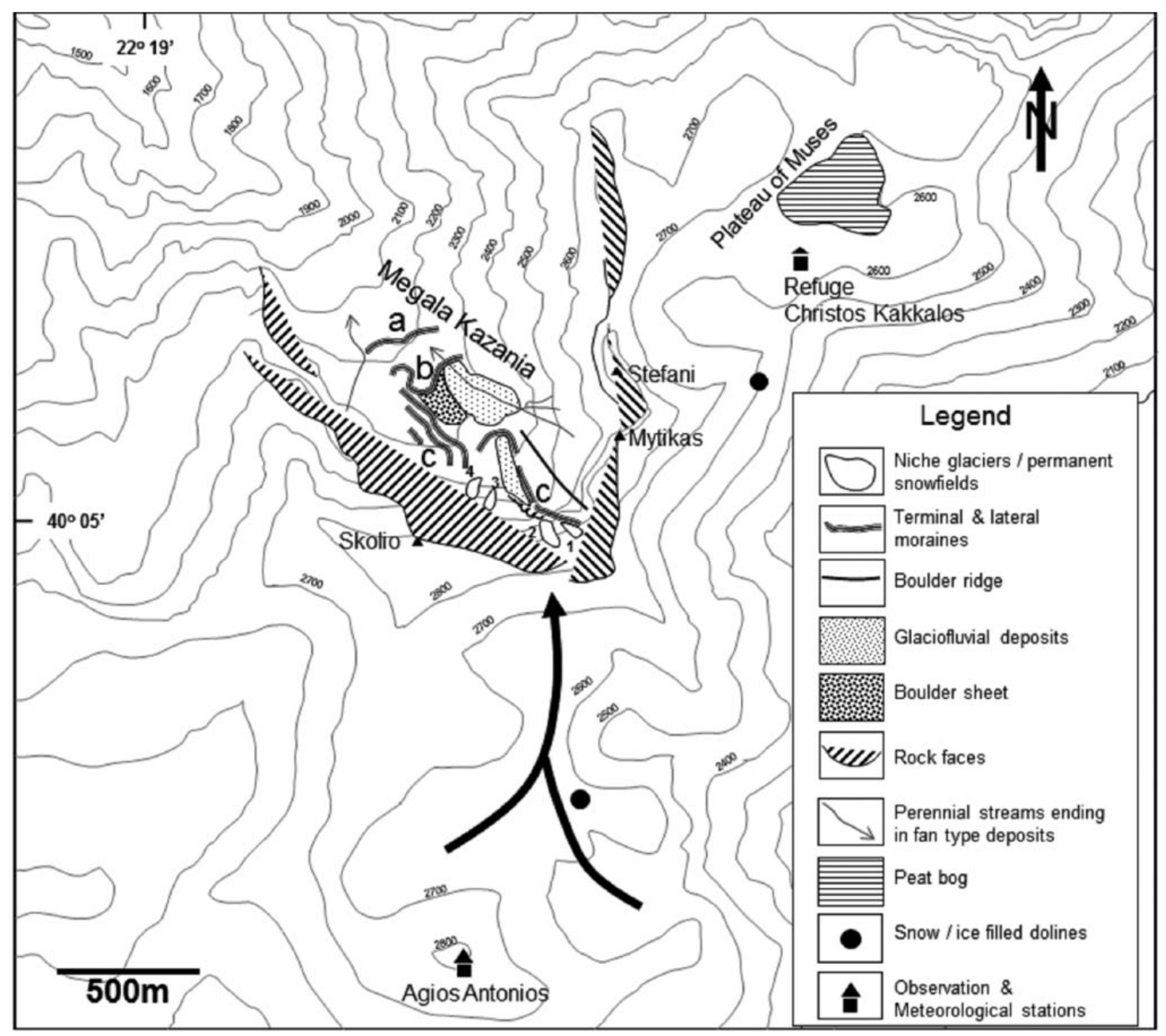

Figure 2. Geomorphological features of the study area. Megala Kazania cirque bounded by steep cliffs is characterized by three sets of end-moraines ( $a, b$, and $c)$. Size and shape of the outermost moraines ' $a$ ' and ' $b$ ' point to extended periods of late Pleistocene glaciation, while geomorphological characteristics of moraine complex 'c' point to Holocene glaciation. Current (AD 2004-20l4) observations and recent evidence (AD 1964-2004, photographs, climbers accounts,) confirm the existence of four (numbered I-4) small permanent snow and ice bodies. The black arrow illustrates the dominant directions (SW, SE) of wind-blown snow inputs that enter the cirque from a high plateau located to the south of Megala Kazania cirque (left of the summit of Skolio in Figure 3).

Olympus comprises a relatively small (surface area: $550 \mathrm{~km}^{2}$, average slope $33^{\circ}$ above the 500-m a.s.l. elevation contour) and isolated massif separated from adjacent Pieria Mountains and Lower Olympus by shallow topographic depressions (Figure 1b).

The massif is composed of metamorphosed and deformed limestones of Triassic and Cretaceous to Eocene age, overlain by a late Eocene flysch (Nance, 2010). The upper mountain between c. 2200 and $2700 \mathrm{~m}$ a.s.l. comprises an SW-tilted planar surface above which several conical peaks arise (Smith et al., 1997). Calcareous texture of basement rocks, intense faulting, and high Pleistocene uplift rates (c. $1.6 \mathrm{~mm} / \mathrm{yr}$, Nance, 2010) have resulted in formation of incised valleys separated by steep ridges. The valley of Megala Kazania is a deep and sheltered U-shaped northwest facing valley (Figure 1a and c). The upper part of the valley comprises a head valley cirque, whereas along its lower part, three well defined moraines, the ages of which remain undetermined, dominate the scenery (Figure 1c; Figure 2 features 'a', 'b', and 'c').

According to Smith et al. (2006), three distinct episodes of Pleistocene glaciation took place on Mount Olympus. Based on results of U/Th disequilibrium dating of a soil sequence proximal to Mount Olympus, the authors correlated the first episode of glacial activity to Marine Isotope Stage (MIS) 8 (Mindel stadial), followed by the Mindel/Riss interstadial, while subsequent episodes of glaciation were linked to Mindel (MIS 6) and Würm
(MIS 4-2) stadials respectively. During the first (MIS 8) episode of glaciation, glaciers occupied the lower parts of the valleys and adjacent piedmonts at distances of $20-25 \mathrm{~km}$ away from their upland sources reaching present-day sea-level locations, as evidenced from the spatial extent of glacial deposits. Uplift corrected ELA during the first episode of glaciation was placed between 500 and $600 \mathrm{~m}$ a.s.1., while during the second glaciation episode glaciers were bounded at mid-valley positions with respective ELA located at $1300 \mathrm{~m}$ a.s.l. The last episode of Pleistocene glaciation (Würm stadial) was confined at higher elevations as uplift corrected ELA was estimated at $2080 \mathrm{~m}$ a.s.l., potentially corresponding to the lower observed moraine (moraine ' $a$ ' in Figure 2) with subsequent elevation of $c .1950 \mathrm{~m}$ a.s.1.

Climate variability in northern Greece during the Lateglacial (late Würm) involved a shift from cold and dry conditions to warm and wet conditions during the Bølling/Allerød interstadial (14.7-12.7 kyr BP), back to cold and dry conditions during the Younger Dryas stadial (12.6-11.7 kyr BP), back to warm and wet early Holocene (11.6-9.6 kyr BP) conditions (Francke et al., 2013; Kotthoff et al., 2011; Lawson et al., 2005). The sequence of these events might be reflected by the observed succession of end-moraines ' $a$ ' and ' $b$ ' at the lower part (1900-2100 m a.s.1.) of the cirque, which are vegetated and covered with soil layers, with the upper moraine (moraine complex 'c') probably representing more recent (Holocene) glacial events (Figures 2 and 3). 


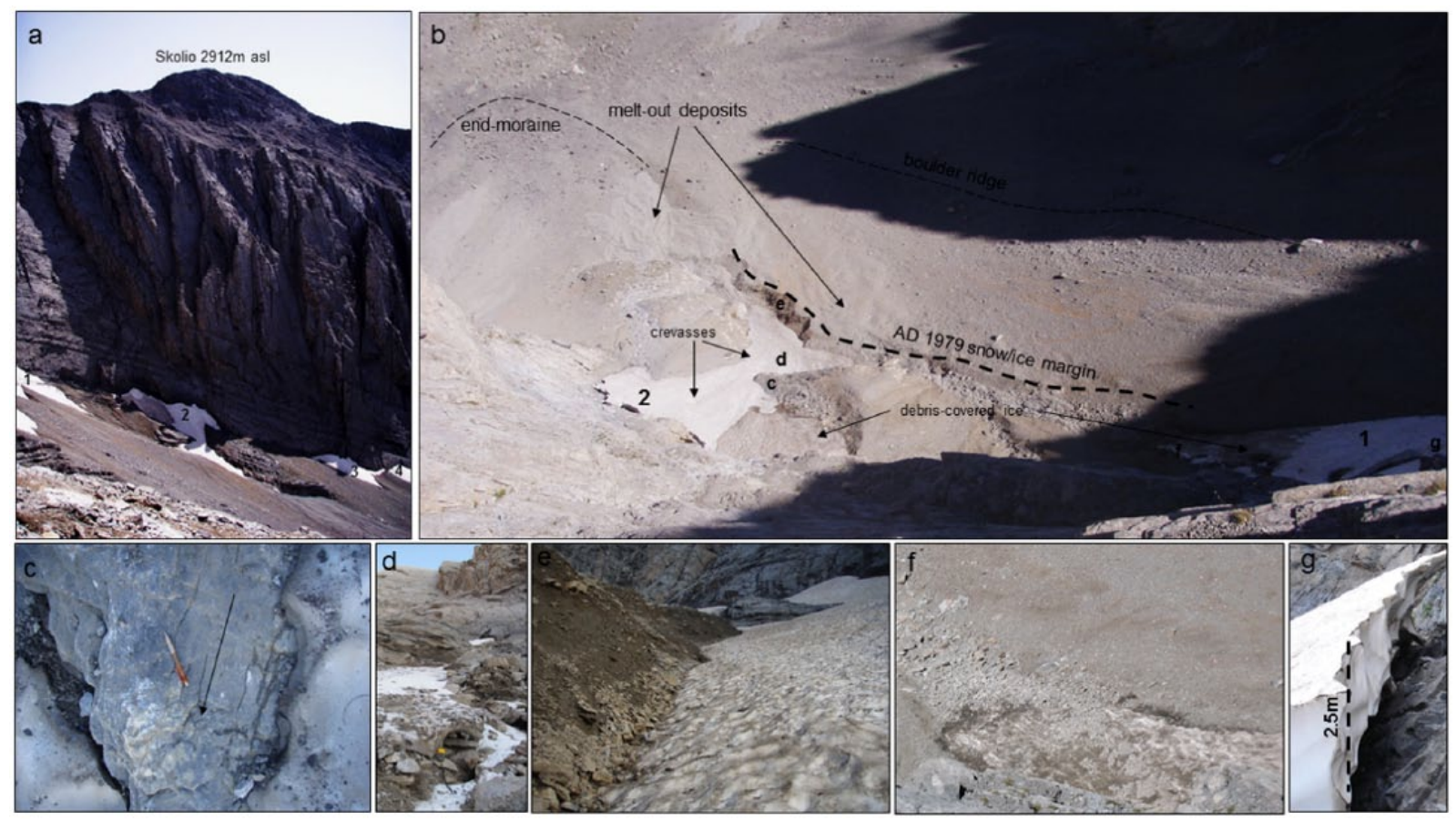

Figure 3. Evidence of current (AD 2004-2014) existence of snow and ice bodies on Mount Olympus: (a) view of Skolio north wall with the four (numbered I-4, also shown in Figures I and 2) surviving permanent snowfields and ice bodies, (b) view from the cliff above of glaciers I and 2, their termini covered with scattered debris, (c) ice-molded bedrock of snow/ice body 2 recently exposed, (d) debris-covered ice exposed during the end of AD 2014 ablation season, (e) lateral moraine bounding permanent snowfield/ice body 2, (f) termini of permanent snowfield I during the summer of AD 2007, when debris-covered ice was exposed, and $(\mathrm{g})$ the distinct bergschrund of permanent snowfield 2 developed beneath the cirque headwall.

Dotted line represents moraine complex 'c' lateral moraine that bounded the AD 1979 snow margin, also shown in Figure I.

\section{Geomorphological evidence}

A total of 24 cirques have been recognized on Mount Olympus (Smith et al., 1997). Among them, Megala Kazania cirque comprises the most characteristic and extensive feature. The cirque's rough topography caught the attention of early explorers who compared it with similar glacial valleys in the Alps. The cirque is bounded by the mountain's highest peaks; Mytikas - $2918 \mathrm{~m}$ a.s.1., Stefani - $2909 \mathrm{~m}$ a.s.1., and Skolio - $2912 \mathrm{~m}$ a.s.1. (Figures $1 \mathrm{c}$ and 3 ).

The cirque backwall, at the foot of which present snow and ice patches exist, is a steep $\left(60-80^{\circ}\right)$ polished and plucked rock face escarped by a series of debris-covered ledges that represent trimlines of past glaciations. Debris supply is high close to cirque walls because of intense weathering of Cretaceous limestones. The permanent snowfields are located in niches at the foot of the backwall and surviving ice is covered with debris, as revealed by the end of the ablation season during mild summers (Figure $3 \mathrm{~d}$ and f). Along the base of the cirque, distinct glacial features including moraines, boulder ridges, bedrock striations, polished surfaces, and crescent scours terminate in a set of well-preserved end-moraines, the highest ones (moraine complex 'c', Figures 2 and 3) located at c. $2200 \mathrm{~m}$ a.s.1.

Moraine complex ' $c$ ' is characterized by excessive boulder and large block accumulations, lacks vegetation and surface soil horizons, and is bounded by a 5-m-high arcuate-shaped ridge crest with a steep outer (downvalley) side, partly overlain by glaciofluvial deposits (Figures 2 and $3 b$ ). In contrast, moraines ' $a$ ' and ' $b$ ' are characterized by deposits of considerably larger grainsizes and are eroded by fluvial action. Behind (upvalley of) the glacial terminus of moraine ' $c$ ', the most recent episodes of glaciation on Mount Olympus are reflected; the multicrested shape and the large range of unsorted grain-sizes typical of moraine deposits suggest activity of either a single cirque glacier or smaller fragmented active glaciers that responded to climate change events with short-lived glacial advance and retreat episodes, the timing of which remains undetermined.

\section{Implications of current and recent glacier activity}

The elevation of moraine complex 'c' corresponds to a cirque height of $c .700 \mathrm{~m}$ (elevation difference between cirque floor $c$. $2200 \mathrm{~m}$ a.s.l. and surrounding peaks c. $2900 \mathrm{~m}$ a.s.1.); the cirque width is $c .1500 \mathrm{~m}$ and cirque surface area is $c .1 .8 \mathrm{~km}^{2}$. Such topographic characteristics constitute an ideal setting for hosting glacial and periglacial features given certain climatic constrains (annual precipitation, summer temperature, and insolation) and other parameters, as shading, reduced ablation, and inputs of wind-blown and avalanching snow from the cirque perimeter.

Present-day permanent snowfields and ice bodies are confined within eroded lateral moraines demonstrating steep inner slopes (Figures 2 and $3 \mathrm{a}$ and e). Excessive snow accumulation also resulting from local topoclimatic factors fills the basins bounded by the older moraines and further protects the debris-covered ice from completely melting out. The presence of high lateral moraines (Figure 3e) indicates a lowering of the ice surface due to increased warming, at least over the past 40 years (see the next section), but the exact timing of this process has yet to be defined. Distant from the outer moraine walls, material becomes coarser with increasing amounts of pebbles, boulders, and large blocks, eventually leading to the terminus of moraine complex ' $c$ '. A glacial origin of these ridges is supported by their distance from the cirque walls, as gravitational transport on firn snow and/or ice cannot explain the boulder size and deposition distance alone. Successive moraine ridges of moraine complex 'c' are well developed, separated by trenches with their outermost part composed of coarse material resting at the angle of repose. The outer terminal moraine part is also characterized by slopewash and reworked glaciofluvial melt-out material 
Table I. Meteorological and glacier variables considered in the study.

\begin{tabular}{lll}
\hline Abbreviation & Variable & Units \\
\hline$P_{a n n}$ & Annual precipitation & $\mathrm{mm}$ \\
$P_{\mathrm{w}}$ & Winter (October-April) precipitation & $\mathrm{mm}$ \\
$P_{\text {as }}$ & Ablation season (May-September) precipitation & $\mathrm{mm}$ \\
$P_{s}$ & Summer (June-July-August) precipitation & $\mathrm{mm}$ \\
$T_{a n n}$ & Annual temperature & ${ }^{\circ} \mathrm{C}$ \\
$T_{\text {as }}$ & Ablation season (May-September) temperature & ${ }^{\circ} \mathrm{C}$ \\
$T_{s}$ & Summer (June-July-August) temperature & ${ }^{\circ} \mathrm{C}$ \\
$\Delta p$ & Precipitation-elevation gradient & $\% \mathrm{~m}$ \\
$\Delta t$ & Altitudinal temperature gradient & ${ }^{\circ} \mathrm{C} / \mathrm{I00} \mathrm{m}$ \\
AIG/TP-ELA & Altitude of instantaneous glacierization, that corresponds to the local & $\mathrm{m}$ \\
& temperature-precipitation equilibrium line altitude & \\
${ }^{\mathrm{C} T P-E L A}$ & Climatic temperature-precipitation equilibrium line altitude & $\mathrm{m}$ \\
NAO & Winter (DJFM) North Atlantic Oscillation Index & - \\
\hline
\end{tabular}

evidenced from the existence of finer alluvial fan-type deposits (Figures 2 and $3 b$ ). Small-sized moraines and boulder ridges also occur in intermediate positions between most recent (closer to backwall) and older moraines, pointing to shorter periods of glacial advance or stillstands of potential Holocene glaciers, as debris-covered cirque glaciers are particularly sensitive to minor climatic oscillations (Zasadni, 2007).

The existence of permanent snowfields and ice bodies in Megala Kazania cirque as well as on other locations of Mount Olympus during the summer is frequently referred to past historical accounts (e.g. Heuzey, 1860; Kurz, 1923; Nezis, 2000). Permanent snowfields that currently survive at the foot of the north facing walls of Megala Kazania cirque (Figure 1d) had a total combined surface area of $0.04 \mathrm{~km}^{2}$ at the end of the AD 2014 ablation season (1 October 2014). Direct observations suggest remarkable fluctuations of the overall snowfield surface area during the last decade (AD 2004-2014). Photographic evidence confirms the overall volume and surface area's decreasing trend, even though in certain years (e.g. AD 2004, 2006) permanent snowfields occupied a considerably larger area compared with AD 2014 but were restricted to positions behind the AD 1980 snow/ ice extent (Figures 1 and 3b). Mount Olympus permanent snowfields and ice bodies survived the warm summers of AD 2003 and 2007, preceded by mild winters, with further reduction in the overall area (c. $0.0017 \mathrm{~km}^{2}$ at the end of AD 2007 ablation season, Figure 3f), but a significant retreat of the debris-covered ice bodies has been observed since AD 2009

\section{Mid- to late-20th-century local climate and ELA reconstructions (AD 1960-2000) and their relation to regional climate modes}

\section{Meteorological data and local climate}

The response of Mount Olympus permanent snowfields and ice bodies to Holocene climate oscillations is expressed by the local ELA fluctuations, mainly induced by local temperature and precipitation variations, but also influenced by cirque topography, and other environmental factors like supply of wind-blown and avalanching snow as well as supply of debris. Comparison of mid to late 20th century (AD 1960-2000) with late, middle, and early Holocene climates is required to shed additional light on paleoclimates that would have favored glacier formation and/or advance.

Mount Olympus' proximity to the sea results in a maritime setting with 'mild' climatic characteristics and temperate glacier formation. Glacier survival in such thermal environment requires large amounts of snow accumulation to balance summer ablation (Ohmura et al., 1992). Local maritime conditions together with
Mount Olympus' steep relief also result in intense precipitation, temperature, and ecotone altitudinal and longitudinal gradients; the highest peaks constituting an orographic and climatic barrier between southeastern (marine) and northwestern (continental) sides. Alpine tree-line is dominated by Pinus Heldreichii and Pinus Nigra and is situated at $2400 \mathrm{~m}$ a.s.l., on the southeastern side (Strid, 1980), being remarkably lower (1900m a.s.l.) on the northwestern side. A pronounced lowering of tree-line elevation occurs within Megala Kazania valley (Figure 1c).

For northern-hemisphere mid-latitude glaciers, annual and winter (October-April) precipitation $\left(P_{a n n}, P_{\mathrm{w}}\right)$ and ablation season (May-September) and summer (June-July-August) temperature $\left(T_{\mathrm{as}}, T_{\mathrm{s}}\right)$ are the main parameters controlling ELA variations (Lie et al., 2003; Ohmura et al., 1992). Winter accumulation is also related to prevailing winds and surface topography (Dahl et al., 1997), while ablation season processes are linked to summer (June-July-August) temperature $\left(T_{s}\right)$, direct solar input, frequency of cloudiness, and shading.

Precipitation and temperature data from eight meteorological stations (Figure 1a) were used to establish Mount Olympus climate characteristics. Temporal gaps in selected time series were resolved by means of linear regression. Meteorological observations from higher elevations are limited, but all available data were utilized to estimate altitudinal variations of precipitation $(\Delta p)$ and temperature $(\Delta t)$ respectively (Table 1$)$. Agios Dimitrios meteorological station located $13 \mathrm{~km}$ north of Megala Kazania cirque (Figure 1a), with 44- and 17-year-long monthly precipitation and temperature observations respectively, was selected as the most representative station to simulate ELA variations in respect to cirque floor elevation (c. $2200 \mathrm{~m}$ a.s.1.). Temperature time series for Agios Dimitrios station were extended through linear regression with the longer data set from Thessaloniki airport ( $90 \mathrm{~km}$ northeast of Megala Kazania cirque, $r>0.9, p<0.001$ ), so $P_{a n n}, P_{\mathrm{w}}$ and $T_{\text {as }}$ and $T_{s}$ data sets cover a 40 -year-long period (AD 1960-2000).

Along the eastern/southeastern flank of the massif, climate is 'mild' with an extended dry period (May-September), typical of Mediterranean areas (Figure 4), while on the northern/northwestern side, climate tends to be more continental, with higher summer (May-September) precipitation and lower mean annual temperatures. At higher elevations (c. 1000-2200 m a.s.1.), climate attains Sub-Mediterranean characteristics, while above c. $2200 \mathrm{~m}$ a.s.l., climate is characterized by temperate conditions with increased amounts of moisture and dry days amounting to less than 20 per annum. Precipitation on the upper mountain between October and May mainly occurs as snow, but snow-depth data are restricted to observations during the last decade. Megala Kazania cirque lies immediately on the lee side of the orographic/climatic barrier and receives large amounts of wind-blown snow on its southwest 

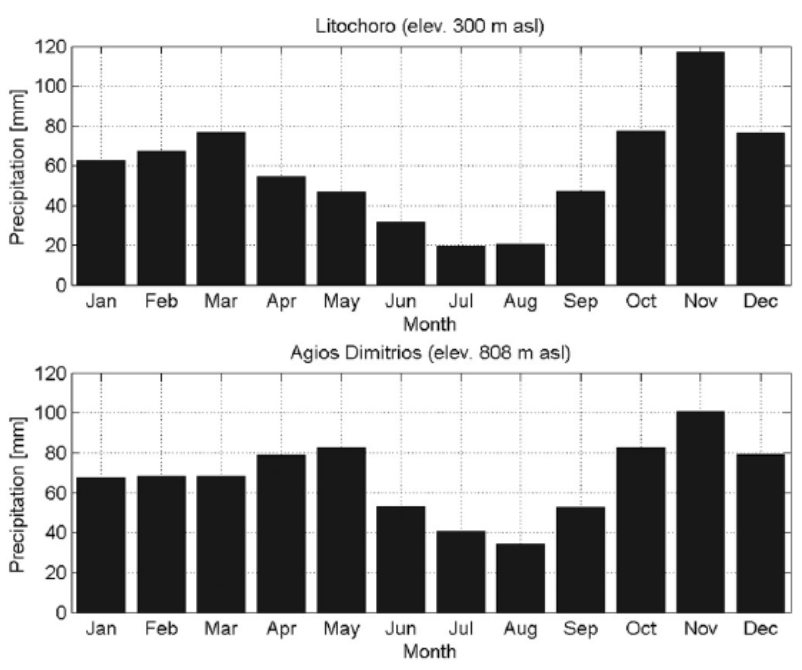

Figure 4. Comparison of mean monthly precipitations (AD 1959-1993) on the eastern (Litochoro) and northwestern (Agios Dimitrios) sides of Mount Olympus.

corner, as this area (northeast of the crest between the summits of Skolio and Skala, Figures 1c and d, 2, and 3a) is characterized by smooth topography and increased snow accumulation. Snow avalanches are frequent from cirque walls and big couloirs to the center of the cirque.

\section{Precipitation}

Winter (October-April) precipitation $\left(P_{\mathrm{w}}\right)$ generally occurs from southeast directions, as moisture-laden fronts from the Aegean Sea are forced on the mountain from prevailing winds, resulting in high precipitation values. Changes in $P_{\mathrm{w}}$ are linked to largescale atmospheric circulation modes, primarily related to enhanced westerlies over the eastern North Atlantic, that result from a rise of mid-tropospheric geopotential over continental Europe (Xoplaki et al., 2001).

The highest amounts of winter precipitation occur when wet fronts from southern Aegean Sea merge with north-northeastern wind outbreaks of polar origin, a situation not infrequent in the vicinity of Mount Olympus, depressing the snowline to very low altitude, even to sea-level. Ablation season (May-September) precipitation $\left(P_{\mathrm{as}}\right)$ is mostly affected from the local orographic setting rather than regional large-scale circulation patterns. Mean annual precipitation $\left(P_{a n n}\right)$ at Vrontou (elevation: $182 \mathrm{~m}$ a.s.1., AD 1975-2002) is $900 \mathrm{~mm} / \mathrm{yr}$, while at Litochoro (elevation: $300 \mathrm{~m}$ a.s.1., AD 1954-1993) it is $700 \mathrm{~mm} / \mathrm{yr}$ (Figure 1a). The northwestern (continental) side of Mount Olympus is affected from the orographic barrier formed by the mountain's highest peaks resulting in rain-shadow effect with $P_{a n n}$ values of $715 \mathrm{~mm} / \mathrm{yr}$ at Livadi (AD 1975-2002) and $809 \mathrm{~mm} / \mathrm{yr}$ at Agios Dimitrios (AD 1957-2001) despite their higher elevations (c. $800 \mathrm{~m}$ a.s.1.).

Monthly precipitation distributions between the southeastern and northwestern side display different patterns. In both cases, precipitation maxima occur during fall/winter (October-November-December), while a second peak occurs during March along the southeastern side and during May along the northwestern side (Figure 4). The fall/winter precipitation maxima in both sides arises from the intensification of general atmospheric circulation patterns along northwestern Aegean Sea driven from rain-bearing winds (southwest, south, southeast) and from a seasonal drop of Aegean Sea surface temperatures (Chronis et al., 2011; Skliris et al., 2011). The observed temporal lag in spring precipitation maxima between maritime (Litochoro) and continental (Agios Dimitrios) sides (Figure 4) is explained by the
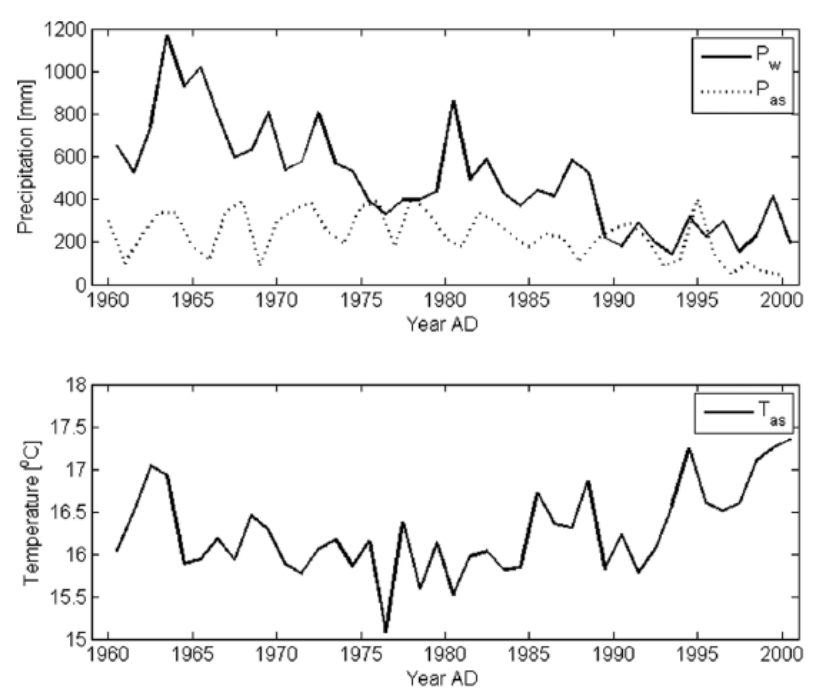

Figure 5. Winter $\left(P_{\mathrm{w}}\right)$ and ablation season $\left(P_{\mathrm{as}}\right)$ precipitation (upper panel) and mean ablation season temperature $\left(T_{\mathrm{as}}\right)$ distribution (lower panel) between AD 1960 and 2000 for Agios Dimitrios meteorological station (elevation: $808 \mathrm{~m}$ a.s.l.).

seasonal (spring/summer) increase of freezing $\left(0^{\circ} \mathrm{C}\right.$ isotherm) altitude that eventually permits moisture-laden orographic clouds to pass over the summit barrier enhancing precipitation on the lee side of Mount Olympus, but also by increased occurrence of spring storms.

Between AD 1960 and 2000, $P_{\text {as }}$ represented 9.5-64\% of $P_{a n n}$ following a different pattern in relation to $P_{\mathrm{w}}$ (Figure 5). Increased amounts of $P_{\text {as }}$ can be an important factor reducing melting especially when combined with below-average summer temperatures $\left(T_{s}\right)$. In such cases, increased $P_{\text {as }}$ results in faster transformation of snowpack to firn snow and/or ice, thus decelerating melting during ablation season. High elevation summer (July-August-September) precipitation values between AD 1963 and 1972 (Agios Antonios station: $2817 \mathrm{~m}$ a.s.l., Figure 1a) vary between 84 and $542 \mathrm{~mm}$, even though precipitation measurements on mountain peaks are not representative because they mainly occur as storms characterized by strong winds. Summer snowfall is not infrequent on Mount Olympus but amounts to only few centimeters and disappears during mid-day. Observations from Agios Antonios meteorological station (Figures 1a and 2) between AD 1963 and 1972 suggest that snowfall contribution to total precipitation was $25 \%$ during the first 20 days of July, 28\% during August, and $47 \%$ during September (Sahsamanoglou, 1977). $P_{\mathrm{w}}$ values between AD 1960 and 2000 display an overall decreasing linear trend with reduced annual variability (Figure 5), attributed to reduced cyclonic circulation over Europe, combined with increased surface continental flows and cooler sea-surface (SST) and air temperatures (Xoplaki et al., 2001), while $P_{\text {as }}$ follows a nonlinear behavior not explained by large-scale circulation patterns (Feidas et al., 2007), as in certain years (AD 1976, 1978, 1990, 1992, 1995) $P_{\text {as }}$ has exceeded $P_{\mathrm{w}}$.

\section{Temperature}

Ablation season temperature $\left(T_{\mathrm{as}}\right)$ also follows a longitudinal trend as more continental conditions prevail on the northwestern side of the mountain. Mean annual temperature at Vrontou station (182 $\mathrm{m}$ a.s.1.) is $T_{a n n}=15^{\circ} \mathrm{C}$, whereas lower values are observed at Agios Dimitrios $\left(T_{a n n}=9.9^{\circ} \mathrm{C}\right.$, elevation: $808 \mathrm{~m}$ a.s.l. $)$ station between $\mathrm{AD} 1975$ and 2002. $T_{s}$ variations display also great variations between Vrontou $\left(22.5^{\circ} \mathrm{C}\right)$ and Agios Dimitrios $\left(17^{\circ} \mathrm{C}\right)$ stations. At Agios Dimitrios station, $T_{\text {as }}$ distribution shows an overall cooling trend along the AD 1960-1980 interval, while between 
AD 1980 and 2000, $T_{\text {as }}$ globally increased steadily (Figure 5), in agreement with the observed trends over Greece (Feidas et al., 2007). Summer cooling is concomitant with increased summer precipitation, as $T_{\text {as }}$ and $P_{\text {as }}$ are negatively correlated $(r=-0.56$, $p<0.001)$ and wet summers between AD 1960 and 1980 combined with $1^{\circ} \mathrm{C} T_{\text {as }}$ decrease may have resulted in receding ablation activity, stabilization of the ice bodies, and subsequent non-fragmentation of Mount Olympus permanent snowfields, evidenced from non-publishable AD 1960 and 1979 aerial photos taken at the end of the ablation seasons.

Near the mountain top, temperature data between AD 1964 and 1976 (Agios Antonios meteorological station, $2817 \mathrm{~m}$ a.s.l., Figure 1a) suggest that the number of days with negative $\left(<0^{\circ} \mathrm{C}\right)$ mean daily temperatures amount to $2.9 \%$ for July, $1.5 \%$ for August, and 9.1\% for September, marking August as the warmest month but supporting the view of cool and wet summers between AD 1965 and 1980 (Sahsamanoglou, 1977).

\section{Altitudinal gradients of precipitation $(\Delta p)$ and temperature $(\Delta t)$}

Extreme local climatic variability, a result of the mountain's intense topography and proximity to sea, is also expressed by steep precipitation and temperature altitudinal gradients. According to data collected from Aristotle University of Thessaloniki (AD 1963-1972), annual precipitation altitudinal variation averaged $c$. $820 \mathrm{~mm} / \mathrm{yr}$ between 300 and $1100 \mathrm{~m}$ a.s.l. and c. $210 \mathrm{~mm} / \mathrm{yr}$ between 1100 and $2800 \mathrm{~m}$ a.s.l. Average precipitation gradients are partitioned between the lower $(<1000 \mathrm{~m}$ a.s.l. $)$ and higher $(>1000 \mathrm{~m}$ a.s.l.) parts of the mountain. Precipitation gradients along lower elevations ( $<1000 \mathrm{~m}$ a.s.l., AD 1963-1972) amount to $\Delta p=102.5 \mathrm{~mm} / 100 \mathrm{~m}(\Delta p=10.25 \% / 100 \mathrm{~m})$, a value in agreement with more recent observations $(\Delta p=12.5 \% / 100 \mathrm{~m}$, Pavlidis and associates, 1995), being considerably lower $(\Delta p=12.35 \mathrm{~mm} / 100 \mathrm{~m}$ or $\Delta p=6 \% / 100 \mathrm{~m}$ ) between 1100 and $2800 \mathrm{~m}$ a.s.1., with average measured precipitation altitudinal gradient of $\Delta p=9 \% / 100 \mathrm{~m}$, over the range of 300 and $2800 \mathrm{~m}$ a.s.l. However, upper mountain precipitation is hard to measure, and thus non-representative and more than $50 \%$ of precipitation occurs as snowfall. Measured snow accumulation varies from tens of centimeters to more than $2.5 \mathrm{~m}$ within wide topographic depressions like the Plateau of Muses next to Refuge Ch. Kakkalos (Figures 1a and 2) and the cirque floor of Megala Kazania (2.8 m measured with stakes in April AD 2012); thus the estimated precipitation gradient value of $\Delta p=9 \% / 100 \mathrm{~m}$ is regarded a conservative estimate.

Summer temperature altitudinal gradients on Mount Olympus have been estimated both for northeastern and southern parts at different time periods. Temperature gradients (AD 1963-1972) for summer months (July-August-September) are $\Delta t=0.8^{\circ} \mathrm{C} / 100 \mathrm{~m}$ between the lower elevations and $2400 \mathrm{~m}$ a.s.l., and $\Delta t=1{ }^{\circ} \mathrm{C}$ $/ 100 \mathrm{~m}$ above $c .2400 \mathrm{~m}$ a.s.1., with average summer temperature altitudinal gradient value of $\Delta t=0.86^{\circ} \mathrm{C} / 100 \mathrm{~m}$ (Sahsamanoglou, 1977). Similar values have been estimated along the northeastern part of Mount Olympus, between Dion (30 m a.s.1.) and Refuge Ch. Kakkalos (2648 m a.s.1.) stations (AD 2013-2014), ranging between $0.32^{\circ} \mathrm{C} / 100 \mathrm{~m}$ in December and $\Delta t=1.08^{\circ} \mathrm{C} / 100 \mathrm{~m}$ in July, with a respective mean for the ablation season (MaySeptember) of $\Delta t=0.8^{\circ} \mathrm{C} / 100 \mathrm{~m}$.

\section{Equilibrium Line Altitude}

ELA is regarded as the most representative parameter to quantify the impact of climate variability on glaciers (Lie et al., 2003). For a specific location, ELA temporal variations depend on the interplay between winter accumulation and summer ablation processes through time and on other local independent variables as topographic characteristics, direct solar input, shading, and albedo
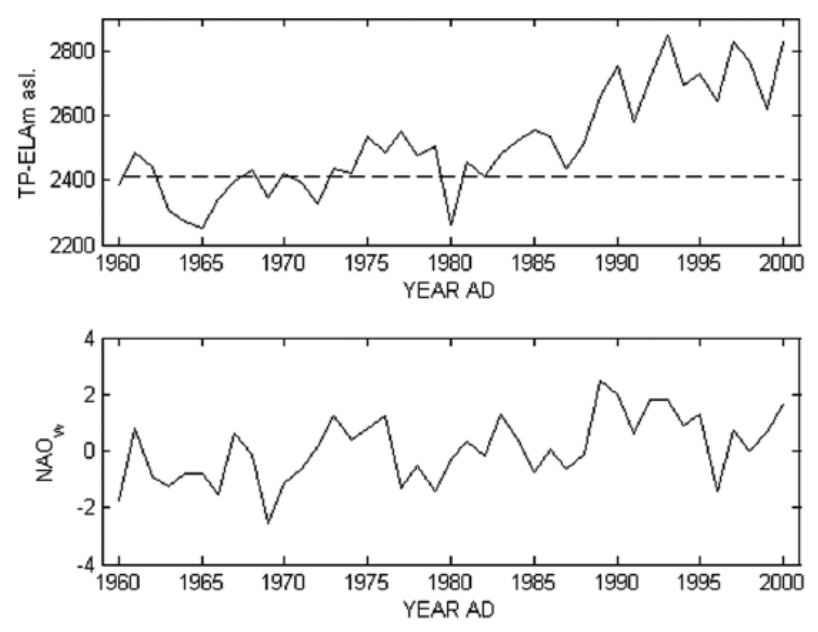

Figure 6. Upper panel: variations of calculated local temperatureprecipitation equilibrium line altitude - TP-ELA. Dotted line corresponds to $2410 \mathrm{~m}$ a.s.l., the upper limit of the present permanent snowfields and ice bodies. Lower panel: winter (DJFM) $\mathrm{NAO}$ index $\left(\mathrm{NAO}_{w}\right)$.

reducing effects (dust deposition, rockfall debris). The climatic characteristics of Agios Dimitrios meteorological station (Figures 4 and 5) are utilized to infer ELA variations in Megala Kazania cirque by implementing the approach, terminology, and equations of Lie et al. (2003).

The authors utilized data from local meteorological stations and presented an empirical relationship between mean ablation season temperature $\left(T_{\mathrm{as}}\right)$ and winter precipitation $\left(P_{\mathrm{w}}\right)$ for 10 Norwegian glaciers representing both maritime and continental climatic settings and furthermore presented equations that led to calculation of (1) 'altitude of instantaneous glacierization - AIG', which corresponds to the calculated value of the observed local temperature-precipitation TP-ELA, (2) 'glacial build up sensitivity-GBS', which is the distance between terrain elevation and of the altitude of theoretical glacier formation taking into account the principle of 'terrain adaption' (Dahl et al., 1997), and (3) the 'climatic temperature-precipitation ELA - 'TP-ELA', defined as the altitude where conditions are favorable for glacier formation. The equations lead to estimates of local TP-ELA, GBS, and ${ }^{\mathrm{c}} \mathrm{TP}-$ ELA and do not take into account other topoclimatic factors as the effect of wind on snow accumulation and shading (Dahl et al., 1997; Lie et al., 2003).

Input variables required to calculate TP-ELA for Megala Kazania cirque between AD 1960 and 2000 are $P_{\mathrm{w}}$ and $T_{\mathrm{as}}$, precipitation-elevation gradient $(\Delta p=9 \% / 100 \mathrm{~m})$, temperature elevation gradient $\left(\Delta t=0.8^{\circ} \mathrm{C} / 100 \mathrm{~m}\right)$, elevation of Agios Dimitrios meteorological station ( $808 \mathrm{~m}$ a.s.1.), and the altitude of Megala Kazania cirque floor (c. $2200 \mathrm{~m}$ a.s.l.). The results suggest a mean TP-ELA for the entire record at $2513 \mathrm{~m}$ a.s.1., $415 \mathrm{~m}$ below Mount Olympus summit (c. $2918 \mathrm{~m}$ a.s.l.), but above the current glacier upper limit (c. $2400 \mathrm{~m}$ a.s.1.).

The climatic temperature-precipitation ELA ( ${ }^{\mathrm{C} T P-E L A)}$ has been estimated further up (c. $2630 \mathrm{~m}$ a.s.l.) for the entire record, but is located above the mountain peak (c. $2945 \mathrm{~m}$ a.s.l.), during the latter part of the record (AD 1990-2000). Between AD 1960 and 1980, TP-ELA is located close to and even below the presentday glacier termini (Figure 6), suggesting that snow and ice bodies attained a stabilization phase between AD 1960 and 1980; a period also characterized by cool and wet summers (see the previous section), as average calculated TP-ELA (c. $2410 \mathrm{~m}$ a.s.1.) is coupled with ${ }^{\mathrm{C}}$ TP-ELA (c. $2485 \mathrm{~m}$ a.s.1.). Permanent snowfields and ice bodies stabilization (AD 1960-1980) is also evidenced through aerial photography with no remarkable changes of overall surface by the end of AD 1960 and 1979 ablation seasons (Figure 1d). The 
resolution of aerial photography does not permit any conclusions whether the permanent snowfields and ice bodies had attained characteristics of a small glacier (e.g. movement, occurrence of crevasses). However, annual variations of TP-ELA during the AD 1960-1980 period displayed considerable variation between $c$. 2250 and c. $2500 \mathrm{~m}$ a.s.l., emphasizing the importance of local topographic and climatic controls. Permanent snowfield and ice stabilization during this period was linked to increased winter and annual precipitation and low ablation season and summer temperatures. Extrapolated climatic parameters $\left(P_{a n n}, P_{\mathrm{w}}, T_{\mathrm{as}}, T_{s}\right)$ to cirque floor (c. $2200 \mathrm{~m}$ a.s.1.) that favored the AD 1960-1980 standstill were: $P_{a n n}=2100 \pm 240 \mathrm{~mm}, P_{\mathrm{w}}=1470 \pm 220 \mathrm{~mm}$ (values not including wind-blown and avalanching snow inputs) and $T_{\text {as }}=4.8 \pm 0.4^{\circ} \mathrm{C}, T_{s}=6.3 \pm 0.4^{\circ} \mathrm{C}$. As heavy winters and mild summers are connected to large-scale atmospheric variations, better understanding about the driving mechanisms of glacierization on Mount Olympus is obtained when reconstructed TP-ELA variations are tested against the regional climate variability modes known to exert control on the climatic variability of northeastern Mediterranean (Figure 6).

\section{Regional climate controls on glaciation regime}

The North Atlantic Oscillation (NAO) exerts strong controls on winter atmospheric circulation in the North Atlantic region and is responsible for winter precipitation, sea-level, and sea-surface temperature (SST) variability over Eastern Mediterranean (Chronis et al., 2011; Hurrell, 1995). NAO index is defined as the difference in standardized winter sea-level pressure between Azores (High) and Iceland (Low), as this difference drives surface winds and winter storms from west to east (Hurrell, 1995). In general, positive $\mathrm{NAO}_{\mathrm{w}}$ values are related with below-normal precipitation over the Mediterranean region (Hurrell, 1995). For the northern Aegean region, positive summer NAO phases are associated with enhanced meridional circulation, relative surface cooling, and increased cloudiness and precipitation over the Greek peninsular and the northern Aegean Sea (Chronis et al., 2011; Klesse et al., 2014).

For Mount Olympus, $\mathrm{NAO}_{\mathrm{w}}$ (leading EOF DJFM PC-time series, Hurrell, 1995) is negatively correlated with $P_{\mathrm{w}}(r=-0.62$, $p<0.0001)$ between AD 1960 and 2000, so that successive years with negative winter (increased $P_{\mathrm{w}}$ ) and positive summer (low $T_{s}$, enhanced cloudiness) NAO index values provide ideal conditions for glacier stabilization and/or advance. NAO driven climatic variability over northern Aegean has been inferred on interannual (Xoplaki et al., 2004), decadal, and centennial timescales (Luterbacher et al., 2010; Trouet et al., 2012). Negative correlation between winter $\mathrm{NAO}_{\mathrm{w}}$ and $P_{\mathrm{w}}$ becomes even higher $(r=-0.71$, $p<0.001)$ when compared with 30-year smoothed reconstructed winter NAO index (Trouet et al., 2009).

Local TP-ELA reconstructions also correlate well $(r=0.60$, $p<0.0001)$ with $\mathrm{NAO}_{\mathrm{w}}$ index on seasonal basis, at $99 \%$ confidence intervals. Negative $\mathrm{NAO}_{\mathrm{w}}$ phases correspond to subsequent lowering of TP-ELA and appear to have favored stabilization of Mount Olympus permanent snowfields and ice bodies during mid to late 20th century. Similar inverse correlations between $\mathrm{NAO}_{\mathrm{w}}$ and glacial advance phases have been found for the Western French Alps (e.g. Guyard et al., 2013), for the Rhone glacier in Valais Alps (e.g. Reichert et al., 2001), and for the Albanian Alps (e.g. Wilkinson, 2011). The sensitivity of glaciers to regional climate raises the question of the past annual precipitation $\left(P_{a n n}\right)$ and summer temperature $\left(T_{s}\right)$ value range combinations that would have favored the formation of a glacier, occupying a larger than the AD 1960-1980 permanent snowfields area, terminating in moraine complex 'c', with a respective 'hypothesized' TP-ELA located at close to glacier terminus (c. $2200 \mathrm{~m}$ a.s.l.) in order to maintain an ice-filled cirque.

\section{Paleoclimate and past TP-ELA implications}

Paleoclimatic conditions during late, mid, and early Holocene are assessed by using the equation by Ohmura et al. (1992) for reconstructing annual precipitation $\left(P_{a n n}\right)$ at the hypothesized TP-ELA (c. $2200 \mathrm{~m}$ a.s.1.) within Megala Kazania cirque. The equation defines the relation between $P_{a n n}$ and $T_{s}$ at any steady state ELA:

$$
P_{a n n}=645+296 T_{s}+9 T_{s}^{2}
$$

More extensive than the mid- to late-20th-century glaciation episodes during the Holocene, with a glacial terminus and respective TP-ELA at c. $2200 \mathrm{~m}$ a.s.l., would have required a TP-ELA depression of c. $210 \mathrm{~m}$ in relation to the AD 1960-1980 TP-ELA (c. $2410 \mathrm{~m}$ a.s.1.). Assuming that equation (1) holds also in the past, such depression can be compensated either from a summer temperature drop of $T_{s}=-2.2^{\circ} \mathrm{C}$ assuming no change in AD 1960 $1980 P_{a n n}(2100 \pm 240 \mathrm{~mm})$ or from an increase in annual precipitation by $P_{a n n}=760 \mathrm{~mm}$, assuming similar summer temperatures to the AD $1960-1980$ mean $T_{s}\left(6.3 \pm 0.4^{\circ} \mathrm{C}\right)$, with all intermediate paleoclimatic combinations considered.

Paleoclimatic considerations for the latest part of the Holocene ('Little Ice Age' (LIA)) are based on $T_{s}$ annual proxy reconstructions from the tree-ring data set provided by Klesse et al. (2014). Additionally, millennial-scale late, mid, and early Holocene paleoprecipitation $\left(P_{a n n}\right)$ estimates at the hypothesized TPELA are based on pollen-based gridded summer temperature $\left(T_{s}\right)$ reconstructions for Europe at 1000-year time-steps (Mauri et al., 2015).

\section{Late-Holocene local climate and ELA response.The LIA}

The later stages of Holocene climate have been characterized by intense climatic oscillations including the well-constrained Medieval Warm (AD 700-1300) and LIA (AD 1300-1850) periods; the latter characterized by pronounced cooling throughout Europe, with considerable but asynchronous glacial advance in the Alps (e.g. Ivy-Ochs et al., 2009) and Norway (e.g. Bakke et al., 2005), that was ultimately followed by the late-20th-century warming trend (Matthews and Briffa, 2005).

Klesse et al. (2014) studied tree-rings from the most dominant species of Mount Olympus' upper tree-line: Pinus Nigra (PINI) and Pinus Heldreichii (PIHE) and provided 400-year-long early summer (May-June-July) precipitation $\left(P_{s}\right)$ and late summer (July-August-September) temperature $\left(T_{s}\right)$ reconstructions based on nine sites (500 samples) from the mountain's eastern (maritime) side. Early summer moisture variability $\left(P_{s}\right)$ was correlated to maximum latewood density (MXD) of Pinus Heldreichii (PIHE), while late summer drought $\left(T_{s}\right)$ on latewood width (LWW) of Pinus Nigra (PINI) respectively (Klesse et al., 2014).

Late summer temperature reconstructions show a continuous decreasing trend between AD 1600 and 1850, with AD 18101820 being the coldest $\left(T_{s}<-2.2^{\circ} \mathrm{C}\right.$ in relation to AD 1950-2010 mean $T_{s}$ value) period of the entire record, while only 2 summers between 18th and 19th centuries rank among the 50 warmest of the record (Figure 7). Between AD 1700 and 1896, summer precipitation $\left(P_{s}\right)$ is steadily decreasing before an abrupt increase at the turn of 20th century with AD 1900-1975 being the wettest early summer period of the entire record (Klesse et al., 2014).

In addition to late Holocene (AD 1500-2000) $T_{s}$ reconstructed values, the use of reconstructed $\mathrm{NAO}_{\mathrm{w}}$ (Luterbacher et al., 2002) is employed to define periods that correspond to increased winter precipitation $\left(P_{\mathrm{w}}\right)$ and potentially to late Holocene glacier formation and/or advance phases (Figure 7).

The variability pattern of the $T_{s} 10$-year running mean, combined with negative $\mathrm{NAO}_{\mathrm{w}}$ values during late Holocene, suggests that climatic conditions (low $T_{s}$, high $P_{\mathrm{w}}$ ) between AD 1680 and 1860 appear as a good candidate to have favored substantial 


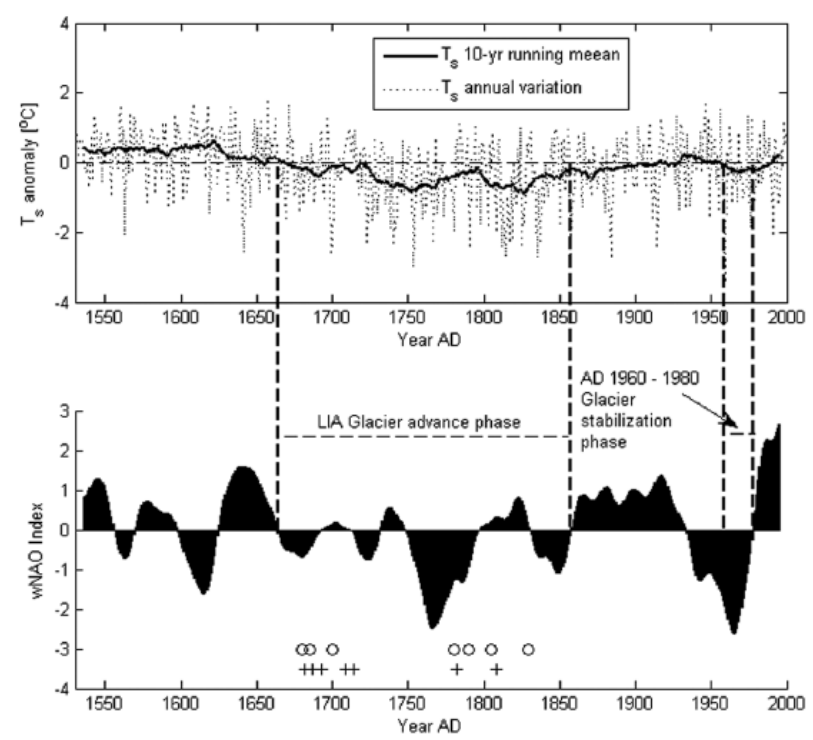

Figure 7. Upper panel: late Holocene (AD I500-2000) summer temperature $\left(T_{s}\right)$ anomaly variations with 10-year running mean in respect to the AD 1950-2010 mean for Mount Olympus eastern (maritime) side (Klesse et al., 2014); and (lower panel) winter NAO index reconstructions (Luterbacher et al., 2002). Bracketed periods are characterized by low $T_{s}$ and mainly negative $\mathrm{NAO}_{\mathrm{w}}$ phases (increased $P_{\mathrm{w}}$, lower TP-ELA), providing favorable conditions for glacier advance. Circles and crosses refer to cold/wet and cold/ dry winters in Greece respectively, inferred from historical records (Xoplaki et al., 200I).

glacier formation and glacial advance (in relation to the AD 1980 termini) phase on Mount Olympus (Figure 7). Reconstructed mean summer temperatures between AD 1680 and 1860 were by $1.1^{\circ} \mathrm{C}$ lower, with mean summer temperature of $T_{s}=5.24 \pm 0.97^{\circ} \mathrm{C}$.

According to (1), such average summer temperature would require mean annual precipitation of $P_{a n n}=2450 \mathrm{~mm}$ at the glacier TP-ELA (c. $2200 \mathrm{~m}$ a.s.1.), or a 350-mm $P_{a n n}$ increase compared with AD 1960-1980 $P_{a n n}$ mean. Extensive periods with negative $\mathrm{NAO}_{\mathrm{w}}$ values (Figure 7) correlate to increased $P_{\mathrm{w}}$ that could have compensated for the additional $350 \mathrm{~mm}$ of $P_{a n n}$ despite the $P_{s}$ decreasing trend (avalanche and wind-blown inputs not included). Vincent et al. (2005) found a 25\% $P_{\mathrm{w}}$ increase between AD 1760 and 1860 in the Alps, supporting the view of considerable glacier advance phase during the latter part of the LIA on Mount Olympus as well.

\section{Early to mid-Holocene regional climate}

Mount Olympus location is within a broader area, which during the Holocene has been influenced both by African monsoonal and North Atlantic weather systems (Kotthoff et al., 2008a). Early to mid-Holocene climate dynamics in the northern Aegean Sea are highly correlated to NAO climate mode systems (rain-bearing westerlies, Chronis et al., 2011; Cullen et al., 2002), but in many occasions have been disturbed by northern latitude climatic intrusions of polar origin (Siberian High, Rohling et al., 2002). Pollenbased climate reconstructions from lacustrine (Tenaghi Phillipon, Nisi Fen) and marine (Mount Athos Basin) sedimentary sequences (Figure 1b) point to an early Holocene (10.4-9.5 kyr BP) climatic period characterized by increased winter precipitation and relatively stable winter temperatures (Kotthoff et al., 2008b). Between 9.5 and $7.8 \mathrm{kyr}$ BP, climate along northern Aegean remained 'mild' (Holocene climate optimum) and was similar to presentday Mediterranean climate, with winter precipitation reaching a maximum and summer precipitation a minimum (Peyron et al., 2011). During this period, a series of short-lived cold and dry

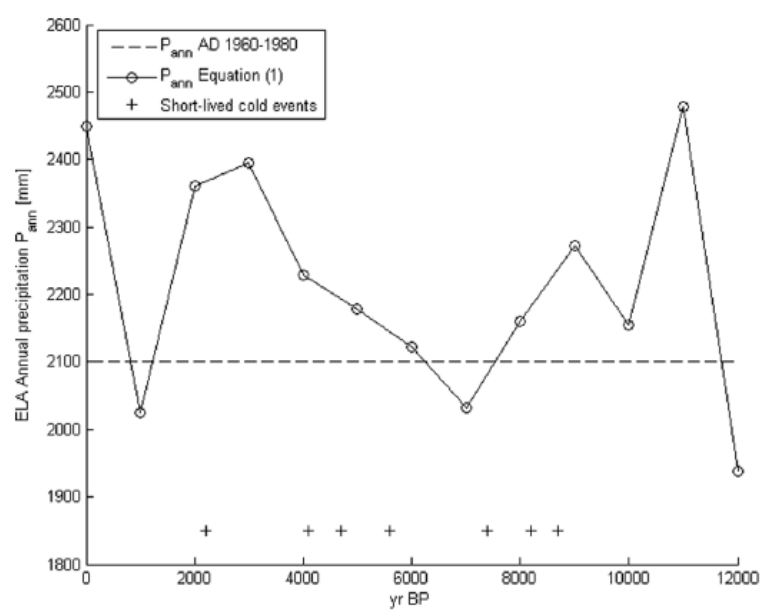

Figure 8. Annual precipitation values inferred from pollen-based reconstructed summer temperatures after Mauri et al. (20I5) through equation ( $\mathrm{I})$, required to maintain a Holocene glacier at the hypothesized TP-ELA (c. $2200 \mathrm{~m}$ a.s.l.). Time intervals (0.27-0.9 and 8-4 kyr BP) characterized with similar $( \pm 100 \mathrm{~mm})$ annual precipitation in relation to the AD 1960-1980 $P_{a n n}$ values comprise the best candidates for glacier formation and/or advance given the influence of local topoclimatic factors. Short-lived cold climatic episodes (marked with crosses) likely caused considerable glacierfront fluctuations that resulted in the formation of boulder ridges and the multicrested morphology of moraine complex ' $c$ '.

(decreased winter precipitation) events between 8.8-8.6, 8.4-8.0, and 7.5-7.2 kyr BP disturbed the 'mild' climate. The most pronounced of these early Holocene climate perturbations is the widespread ' 8.2 kyr event' (Francke et al., 2013; Kotthoff et al., 2008a; Rohling et al., 2002; Weningher et al., 2009) characterized by dry winters, wet summers, and an overall drop in mean annual temperature of more than $T_{a n n}=-4^{\circ} \mathrm{C}$ (Pross et al., 2009).

Mid to late Holocene climate in southern Europe was characterized by a general summer cooling trend (Davis et al., 2003), observed also in the Aegean Sea region (Dormoy et al., 2009; Geraga et al., 2010). This summer cooling trend co-occurred with a drying trend (cool dry summers), which at Tenaghi Phillipon (Figure 1b) was translated to an overall $P_{a n n}$ reduction from 800 to $600 \mathrm{~mm}$, still higher than present-day values between 8 and $6 \mathrm{kyr}$ BP (Peyron et al., 2011). The mid-Holocene (8-4 kyr BP) overall stable conditions characterized by a summer cooling and drying trend and higher-than-present annual precipitation were superimposed by a series of accentuated dry and cold peaks centered around 5.6 (end of African humid period), 4.7, 4.1, and 2.2 kyr BP (Francke et al., 2013; Kotthoff et al., 2008b). On Mount Olympus, these short-lived cold events are likely to have triggered considerable fluctuations of preexisting mid Holocene glaciers that resulted in the multicrested morphology of moraine complex ' $c$ ', but the response of Mediterranean glaciers to such short-lived cold and dry events has yet to be studied.

Independent summer paleotemperature $\left(T_{s}\right)$ estimates derived from the pollen-based gridded climatology provided by Mauri et al. (2015) and more specifically, $T_{s}$ extrapolated from the grid-cell centered at $40^{\circ} \mathrm{N}, 22^{\circ} \mathrm{E}$ (Basil Davies pers. comm.) provide a Holocene average summer temperature of $T_{s}=4.6 \pm 0.4^{\circ} \mathrm{C}$, thus requiring, according to (1), an average annual precipitation of $P_{a n n}=2160 \pm 160 \mathrm{~mm}$ for an extended glacier to survive at the hypothesized TP-ELA (c. $2200 \mathrm{~m}$ a.s.l.). This value is similar to AD $1960-1980$ period $\left(P_{a n n}=2100 \pm 240 \mathrm{~mm}\right)$, supporting the hypothesis of Holocene glaciation on Mount Olympus. However, paleoclimatic conditions in the area were not uniform but demonstrated considerable variability throughout the Holocene restricting the periods that potentially favored glacier formation and glacial advance between $0.27-0.9$ and 8-4 kyr BP respectively (Figure 8). 


\section{Discussion}

Small extant permanent snowfields and disappearing ice bodies on Mount Olympus located in favorable sites within Megala Kazania cirque are a product of the local topoclimatic regime as the TP-ELA is currently above the mountain summit (c. $2918 \mathrm{~m}$ a.s.1.). The situation is similar with other locations in Mediterranean region and Balkan Peninsular. The findings of recent studies confirm the existence of glaciers in the Balkans; Debeli Namet glacier on Montenegro's Durmitor Massif (Hughes, 2010), Snezhnika glacieret on Bulgarian Pirin Mountains (Grunewald and Scheithauer, 2010), of the small glaciers on Mount Proktletje (Albanian Alps) at approximately c. $2400 \mathrm{~m}$ a.s.l. (Hughes, 2009; Wilkinson, 2011), and of the Jou Negro ice patch late Holocene and recent evolution on Spain's Cantabrian mountain range (Serrano et al., 2011), despite the post AD 1980 warming trend, indicate a similar situation to Mount Olympus and emphasize the impact of local topographical and climatic controls to the survival of Europe's southernmost glaciers, permanent snowfields, and ice bodies. Despite Mount Olympus' even southernmost positioning in relation to the rest of Balkan glaciers, the significance of local topoclimate is enhanced by the mountain's close proximity ( $c$. $18 \mathrm{~km}$ ) to the Aegean Sea that results in a maritime setting similar to that of present-day Norwegian glaciers.

Paleoclimate reconstructions, existence of boulder ridges, and the multicrested nature of the highest terminal moraine complex 'c' (c. $2200 \mathrm{~m}$ a.s.1.) on Mount Olympus point to multiple episodes of glacial advance and retreat during the Holocene. Moraine ridges close to cirque headwall (c. $2300 \mathrm{~m}$ a.s.l.) are likely related to the LIA and were reoccupied by permanent snow and ice bodies during the AD 1960-1980 stabilization phase concomitant with similar glacial stillstands in the Alps (Zemp et al., 2007), in Picos De Europa (Serrano et al., 2011), and in Proktletje mountains of Albania-Montenegro (Wilkinson, 2011). The influence of NAO has likely played an important role in the overall Holocene glacier evolution as $\mathrm{NAO}_{\mathrm{w}}$ demonstrates significant inverse correlation with variations of TP-ELA on Mount Olympus. Pronounced correlations between $\mathrm{NAO}_{\mathrm{w}}$ and glacier fluctuations have also been found for Norwegian maritime glaciers, while more continental settings in the European Alps tend to be anticorrelated with $\mathrm{NAO}_{\mathrm{w}}$ at certain time intervals (e.g. Guyard et al., 2013; Imhof et al., 2012; Reichert et al., 2001).

LIA terminal moraines are expected to be located further down valley and closer to cirque floor in relation to AD 1980 permanent snow terminus, since the period between AD 1680 and 1860 is characterized by lower summer temperatures $\left(T_{s}\right)$ and negative $\mathrm{NAO}_{\mathrm{w}}$ phases associated with increased winter and annual precipitation $\left(P_{\mathrm{w}}, P_{a n n}\right)$. According to tree-ring paleotemperature reconstructions (Klesse et al., 2014) and equation (1), an LIA (AD 1680-1860) glacier advance with its terminus at moraine complex 'c' (c. $2200 \mathrm{~m}$ a.s.1.) would have required average annual precipitation of $P_{a n n}=2450$ or $350 \mathrm{~mm}$ of annual precipitation surplus at the hypothesized ELA (c. $2200 \mathrm{~m}$ a.s.1.). This amount could have been compensated either from local topoclimate (wind-blown and avalanching snow), or from wetter conditions that prevailed during LIA, also evidenced in the Alps, or from a combination of both.

Historical accounts refer to successive periods of extremely cold and wet winters between AD 1680 and 1860 (Figure 7). Some years were exceptionally cold and winter conditions harsh, characterized by excessive snow accumulation as for example year AD 1700, when mountains of Crete (southernmost island of Greece) were covered with year-round snow, or like AD 1808 and 1829 winters when several lakes in north and central Greece were frozen throughout the winter (Xoplaki et al., 2001). On Mount Olympus, scarce accounts exist for the AD 1680-1860 period. Attempts to reach the highest summits of the mountain were abandoned because of excessive snow accumulation. French climber G Poqueville's efforts to reach the highest point of Mount
Olympus at the end of July AD 1810 were thwarted by excessive snow and icy conditions at $2500 \mathrm{~m}$ a.s.l. The inaugural ascent to the mountain's highest peak on 2 August AD 1913 was realized in much colder and rainier conditions than those at present, as climbers had to battle with negative temperatures, rain, fog, and also had to cross numerous snowfields along the eastern side of the mountain (Nezis, 2000).

LIA glaciation has also been documented in Italy (Giraudi, 2005), Spain (González-Trueba et al., 2008), as well as for other parts of Mediterranean (Hughes, 2014). In Balkan peninsula, lichenometric dated moraines of LIA age have also been found on Durmitor Massif, where ELA was estimated at c. $2130 \mathrm{~m}$ a.s.1. (Hughes et al., 2011), while LIA glaciers of Mount Proktletje occupied an area $70 \%$ larger than present (Wilkinson, 2011). Late Holocene glacial history of Mount Proktletje was characterized by four discrete glacial extend episodes, as Maja e Koljaet glacier area was reduced from 0.54 to $0.084 \mathrm{~km}^{2}$ between AD 1800 and 2009 (Wilkinson, 2011), supporting the potential occurrence of glaciation on Mount Olympus during the LIA. Prior to the LIA, climate was characterized by average summer temperatures of $0.29 \pm 0.8^{\circ} \mathrm{C}$ above the mid-20th-century mean during a 160 -year-long period (AD 1520-1680); a period characterized by remarkable summer temperature variability (Klesse et al., 2014).

Paleoprecipitation reconstructions for mid and early Holocene in 1000-year intervals through application of equation (1) by using pollen-based paleotemperature estimates by Mauri et al. (2015) demonstrate remarkable millennial-scale paleotemperature variations being higher compared with the LIA (e.g. $T_{s}$ anomaly between 0.1 and $1.0 \mathrm{kyr}$ BP was $-1.51^{\circ} \mathrm{C}$ compared with the last century, while $T_{s}$ anomaly was $-1.2^{\circ} \mathrm{C}$ between 8 and $4 \mathrm{kyr}$ $\mathrm{BP})$ marking the mid-Holocene period ( $8-4 \mathrm{kyr} \mathrm{BP})$ as another period with favorable conditions to glacial advance, likely similar to conditions which prevailed during the LIA (Figure 8) and concomitant with the globally observed Neoglacial glacier readvances (Solomina et al., 2008). Timing and expanse of Mount Olympus glaciers to the mid-Holocene short-lived cold episodes have yet to be defined, especially since the reaction of small temperate snow and ice bodies and glaciers, like the ones studied here, to such climatic anomalies cannot be reconstructed with existing data.

\section{Conclusion}

At present, small permanent snowfields and ice bodies exist on the lee side of Mount Olympus' highest peaks in Megala Kazania cirque, as a result of local topoclimatic factors, shading, and input of large amounts of wind-blown and avalanching snow. Snow and ice bodies are fragmented and covered a total combined area of $0.04 \mathrm{~km}^{2}$ by the end of the AD 2014 ablation season.

The last phase of stabilization on Mount Olympus took place between AD 1960 and 1980, and since then permanent snowfields and ice bodies have entered a general shrinking phase, with remarkable annual surface area variations associated with winter precipitation $P_{\mathrm{w}}$. Mid- to late-20th-century (AD 1960-1980) stabilization resulted from increased annual precipitation $\left(P_{a n n}=2100 \pm 240 \mathrm{~mm}\right)$ and low summer temperatures $\left(T_{s}=6.3 \pm 0.4^{\circ} \mathrm{C}\right)$, with an average local TP-ELA being slightly above the upper snow and ice limit (c. $2410 \mathrm{~m}$ a.s.1.), manifesting the significance of local topoclimatic factors (shading, inputs of wind-blown and avalanching snow) in past glacier oscillations and present survival of Mount Olympus glaciers.

The influence of the NAO has most likely played an important role in the permanent snowfields, ice bodies, and glaciers evolution during the Holocene. $P_{\mathrm{w}}$ annual and multidecadal (30 years) and TP-ELA variations correlate well with winter NAO index $(r=-0.62, \quad p<0.0001, \quad r=-0.71, \quad p<0.0001, \quad$ and $r=0.60$, $p<0.0001$, respectively). Negative $\mathrm{NAO}_{\mathrm{w}}$ phases correspond to 
increased winter precipitation, lowering of TP-ELA, and subsequent permanent snowfield, ice body, and/or glacier stabilization or advance also evidenced during AD 1960-1980 stabilization phase, confirmed from aerial photographs.

The hypothesis of glacier existence in Megala Kazania cirque with a terminus at moraine complex 'c' (c. $2200 \mathrm{~m}$ a.s.l.) and respective TP-ELA at $2200 \mathrm{~m}$ a.s.1. (below the cirque backwall and close to the observed end-moraine) during the Holocene is tested by using the global data set and equation by Ohmura et al. (1992).

A larger-than-present permanent snowfield and ice body extent during the late Holocene (LIA) appears realistic and could have potentially resulted in the formation of a glacier, since LIA climate reconstructions of summer temperatures point to lower summer temperatures and to successive periods with negative $\mathrm{NAO}_{\mathrm{w}}$ index between AD 1680 and 1860. According to equation (1), average summer temperatures of $T_{s}=5.24 \pm 0.97^{\circ} \mathrm{C}$ would require average annual precipitation of $P_{a n n}=2400 \mathrm{~mm}$ at the hypothesized TP-ELA. The additional $P_{a n n}=350 \mathrm{~mm}$ in relation to AD 1960-1980 mean could have compensated either from increased winter precipitation resulted from low $\mathrm{NAO}_{\mathrm{w}}$ values and manifested from historical evidence, or from increased inputs of wind-blown and avalanching snow, factors that play a very important role to mid- to late-20th-century glacier survival.

Also, paleoprecipitation reconstructions at the hypothesized TP-ELA (c. $2200 \mathrm{~m}$ a.s.1.) during mid Holocene point the 8-4 kyr BP period (Neoglacial) as another climatic favorable interval of glaciation, similar to the LIA. Existence of short-lived cold events in north Aegean region is considered to have triggered glacier fluctuations partially explaining the multicrested shape of moraine complex 'c'.

Based on the presented observations and despite the absence of age constraints for the existing moraines, we suggest that the perception of glacier-free conditions in Greece during the Holocene is a legacy. A recent (AD 1960-1980) permanent snowfield and ice stabilization phase at our study site is evidenced by aerial photos, in line with morphological and meteorological observations. Paleoclimate reconstructions point to more extensive than mid- to late-20th-century glacierization at least during the later part of the LIA and mid-Holocene, while the multicrested nature of moraine complex 'c' could be interpreted as glacial response to higher (sub-millennial) frequency climate oscillations recorded along northern Aegean region.

Further work in Mount Olympus is focusing on dating the extent of the Holocene glacier advance phases by means of in situ ${ }^{36} \mathrm{Cl}$ cosmogenic dating and on a detailed description of paleoclimatic conditions based on sedimentary sequences from alpine peat bogs and from proglacial and lacustrine environments.

\section{Acknowledgements}

The authors are grateful to two anonymous reviewers for their helpful comments.

\section{Funding}

This research was supported by the John S. Latsis Foundation as part of the 2015 Scientific Studies project entitled 'Did the Ancient Greek Gods ever get Cold? Defining the Holocene glacial history of Mount Olympus, Greece'.

\section{References}

Bakke J, Dahl SO, Paasche Ø et al. (2005) Glacier fluctuations, equilibrium-line altitudes and paleoclimate in Lyngen northern Norway during the Lateglacial and Holocene. The Holocene 15: 518-540.

Brown J, Harper J and Humphrey N (2010) Cirque glacier sensitivity to $21^{\text {st }}$ century warming: Sperry Glacier, Rocky Mountains, USA. Global and Planetary Change 74(2): 91-98.
Chronis T, Raitsos DE, Kassis D et al. (2011) The Summer North Atlantic Oscillation influence in the Eastern Mediterranean. Journal of Climate 24: 5584-5596.

Cullen HM, Kaplan A, Arkin PA et al. (2002) Impact of the North Atlantic Oscillation on middle eastern climate and streamflow. Climate Change 55: 315-338.

Dahl SO, Bakke J, Lie O et al. (2003) Reconstruction of former glacier equilibrium-line-altitudes based on proglacial sites: An evaluation of approaches and selection of sites. Quaternary Science Reviews 22: 275-287.

Dahl SO, Nesje A and Øvstedal J (1997) Cirque glaciers as a morphological evidence for a thin Younger Dryas ice-sheet in east-central southern Norway. Boreas 26: 161-180.

Davis BAS, Brewer S, Stevenson AC et al. (2003) The temperature of Europe during the Holocene reconstructed from pollen data. Quaternary Science Reviews 22: 1701-1716.

Dormoy I, Peyron O, Combourieu-Nebout N et al. (2009) Terrestrial climate variability and seasonality changes in the Mediterranean region between 15,000 and 4,000 years BP deduced from marine pollen records. Climate of the Past 5: 615-632.

Feidas H, Noulopoulou H, Makrogiannis T et al. (2007) Trend analysis of precipitation time series in Greece and their relationship with circulation using surface and satellite data: 1955-2001. Theoretical Applied Climatology 87: 155-177.

Francke A, Wagner B, Leng MJ et al. (2013) A late glacial to Holocene record of environmental change from lake Dorjan (Macedonia, Greece). Climate of the Past 9: 481-498.

Geraga M, Ioakim C, Lykousis V et al. (2010) The high resolution palaeoclimatic and palaeoceanographic history of the last 24,000 years in the central Aegean Sea, Greece. Palaeogeography, Palaeoclimatology, Palaeoecology 287: 101-115.

Giraudi C (2005) Middle to Late Holocene glacial variations, periglacial processes and alluvial sedimentation in the higher Apennine massifs (Italy). Quaternary Research 64: 176-184.

González-Trueba JJ, Martin Moreno R, Martínez De Pisón E et al. (2008) Little Ice Age glacier advance and current glaciers in Iberian Peninsula. The Holocene 18: 551-568.

Griffiths HI, Krystufek B and Reed JM (2004) Balkan Biodiversity: Pattern and Process in the European Hotspot. Dordrecht: Kluwer Academic Publishers.

Griggs C, DeGaetaneo A, Kuniholm P et al. (2007) A regional high-frequency reconstruction of May-June precipitation in the north Aegean from oak tree-rings AD 1089-1989. International Journal of Climatology 27: 1075-1089.

Grunewald K and Scheithauer J (2010) Europe's southernmost glaciers: Response and adaptation to climate change. Journal of Glaciology 56: 129-142.

Guyard H, Charpon E, St-Onge G et al. (2013) Late-Holocene NAO and oceanic forcing on high-altitude proglacial sedimentation (Lake Bramant, Western French Alps). The Holocene 23(8): 1163-1172.

Heuzey L (1860) Le Mont Olympe et l'Acarnanie. Exploration de ces deux regions, avec le etude leurs antiquites, de leurs populations anciennes et modernes, le leur geographie et de leur histoire. Ouvrage accompagne de planches. Paris: Frimin-Didot.

Hughes PD (2008) Response of a Montenegro glacier to extreme summer heatwaves in 2003 and 2007. Geografiska Annaler 90: 259-267.

Hughes PD (2009) Twenty-first century glaciers in the Prokletije Mountains, Albania. Arctic, Antarctic and Alpine Research 41: 455-459.

Hughes PD (2010) Little Ice Age glaciers in the Balkans: Low altitude glaciation enabled by cooler temperatures and local topoclimatic controls. Earth Surface Processes and Landforms 35: 229-241. 
Hughes PD (2014) Little Ice Glaciers in Mediterranean mountains. Mediterraneé 122: 45-61.

Hughes PD, Gibbard PL and Woodward JC (2003) Relict rock glaciers as indicators of Mediterranean paleoclimate during the last glacial maximum (Late Wurmian), in northwest Greece. Journal of Quaternary Science 18(5): 431-440.

Hughes PD, Gibbard PL and Woodward JC (2007) Geological controls on Pleistocene glaciation and cirque form in Greece. Geomorphology 88: 242-253.

Hughes PD, Woodward JC and Gibbard PL (2006) The last glaciers of Greece. Zeitschrift für Geomorphologie 50: 37-61.

Hughes PD, Woodward JC, Calsteren Van et al. (2011) The glacial history of the Dinaric Alps, Montenegro. Quaternary Science Reviews 30: 3393-3412.

Hurrell JW (1995) Decadal trends in the North Atlantic Oscillation and relationships to regional temperature and precipitation. Science 269: 676-679.

Imhof P, Nesje A and Nussbaumer SU (2012) Climate and glacier fluctuations at Jostedalsbreen and Folgefonna, southwestern Norway and in the western Alps from the 'Little Ice Age' until the present: The influence of the North Atlantic Oscillation. The Holocene 22(2): 235-247.

Ivy-Ochs S, Kerschner H, Maisch M et al. (2009) Latest Pleistocene and Holocene glacier variations in the European Alps. Quaternary Science Reviews 28: 2137-2149.

Klesse S, Ziehmer M, Rousakis G et al. (2014) Synoptic drivers of 400 years of summer temperature and precipitation variability on Mt. Olympus, Greece. Climate Dynamics. Epub ahead of print 9 September. DOI 10.1007/s00382-014-2313-3.

Kotthoff U, Koutsodendris A, Pross J et al. (2011) Impact of Lateglacial cold events on the northern Aegean region reconstructed from marine and terrestrial proxy data. Journal of Quaternary Science 26(1): 86-96.

Kotthoff U, Müller UC, Pross J et al. (2008a) Climate dynamics in the borderlands of the Aegean Sea during formation of Sapropel S1 deduced from a marine pollen record. Quaternary Science Reviews 27: 832-845.

Kotthoff U, Müller UC, Pross J et al. (2008b) Lateglacial and Holocene vegetation dynamics in the Aegean region: An integrated view based on pollen data from marine and terrestrial archives. The Holocene 18: 1019-1032.

Kuhlemann J, Milivojevič M, Krumrei I et al. (2009) Last glaciation of the Šara Range (Balkan Peninsula): Increasing dryness from the LGM to the Holocene. Austrian Journal of Earth Sciences 102: 146-158.

Kurz M (1923) Le Mont Olympe (Thessalie). Paris; Neuchatel: Victor Attinger.

Lawson I, Al-Omari S, Tzedakis PC et al. (2005) Lateglacial and Holocene vegetation history at Nisi Fen and the Boras mountains, Northern Greece. The Holocene 15: 873-887.

Lie O, Dahl SO and Nesje A (2003) A theoretical approach to glacier equilibrium-line altitudes using meteorological data and glacier mass-balance records from southern Norway. The Holocene 13(3): 365-372.

Luterbacher J, Koenig SJ, Franke J et al. (2010) Circulation dynamics and its influence on European and Mediterranean January-April climate over the past half millennium: Results and insights from instrumental data, documentary evidence and coupled climate models. Climate Change 101: 201-234.

Luterbacher J, Xoplaki E, Dietrich D et al. (2002) Reconstruction of sea level pressure fields over the Eastern North Atlantic and Europe back to 1500. Climate Dynamics 18: 545-561.

Matthews JA and Briffa KR (2005) The 'Little Ice Age': Reevaluation of an evolving concept. Geografiska Annaler 87: $17-36$.
Mauri A, Davies BAS, Collins PM et al. (2015) The climate of Europe during the Holocene: A gridded pollen-based reconstruction and its multi-proxy evaluation. Quaternary Science Reviews 112: 109-127.

Milivojevič M, Menkovič M and Calič J (2008) Pleistocene glacial relief of the central part of Mt. Prokletije (Albanian Alps). Quaternary International 190(1): 112-122.

Nance RD (2010) Neogene - Recent extension on the eastern flank of Mount Olympus, Greece. Tectonophysics 488: 282-292.

Nezis N (2000) Olympus. Athens: Hellenic Mountaineering and Climbing Federation (in Greek).

Ohmura A, Kasser P and Funk M (1992) Climate at the equilibrium line of glaciers. Journal of Glaciology 38: 397-411.

Pavlidis T and associates (1995) An evaluation of water resources of Enipeas River, Mount Olympus, Greece. Forestry Department, Aristotle University of Thessaloniki.

Peyron O, Goring S, Dormoy I et al. (2011) Holocene seasonality changes in the central Mediterranean region reconstructed from the pollen sequences of Lake Accesa (Italy) and Tenaghi Philippon (Greece). The Holocene 21(1): 1-16.

Pross J, Kotthoff U, Müller UC et al. (2009) Massive perturbation in terrestrial ecosystems of the eastern Mediterranean region associated with the 8.2 kyr climatic event. Geology 37 : 887-890.

Reichert BK, Bengtsson L and Oerlemans J (2001) Midlatitude forcing mechanisms for glacier mass balance investigated using general circulation models. Journal of Climate 14: 3767-3784.

Rohling E, Mayewski P, Abu-Zied R et al. (2002) Holocene atmosphere-ocean interactions: Records from Greenland and the Aegean Sea. Climate Dynamics 18: 587-594.

Sahsamanoglou H (1977) Mount Olympus Massif as a lower troposphere heat source. $\mathrm{PhD}$ Thesis, Aristotle University of Thessaloniki.

Serrano E, González-Trueba JJ, Sanjojé JJ et al. (2011) Ice patch origin, evolution and dynamics in a temperate high mountain environment: The Jou Negro, Piocs De Europa (SW Spain). Geografiska Annaler 57-70.

Skliris N, Sofianos SS, Gkanasos A et al. (2011) Long-term sea surface temperature variability in the Aegean Sea. Advances in Oceanography and Limnology 2(2): 125-139.

Smith GW, Nance RD and Genes AN (1997) Quaternary glacial history of Mount Olympus, Greece. Geological Society of American Bulletin 109: 809-824.

Smith GW, Nance RD and Genes AN (2006) Pleistocene glacial history of Mount Olympus, Greece: Neotectonic uplift, equilibrium line elevations, and implications for climatic change. Geological Society of America Special Papers 409: 157-174.

Solomina O, Haeberli W, Kull C et al. (2008) Historical and Holocene glacier-climate variations: General concepts and overview. Global and Planetary Change 60: 1-9.

Strid A (1980) Wild Flowers of Mount Olympus. Athens: Goulandris Natural History Museum.

Trouet V, Esper J, Graham NE et al. (2009) Persistent positive North Atlantic Oscillation mode dominated the Medieval Climate Anomaly. Science 324: 78-80.

Trouet V, Panayotov MP, Ivanova A et al. (2012) A pan-European summer teleconnection mode recorded by a new temperature reconstruction from the northeastern Mediterranean (AD 1768-2008). The Holocene 22: 887-898.

Tzedakis PC (2007) Seven ambiguities in the Mediterranean palaeoenvironmental narrative. Quaternary Science Reviews 26: 2042-2066.

Vincent C, Le Meur E and Six D (2005) Solving the paradox of the end of the Little Ice Age in the Alps. Geophysical Research Letters. Epub ahead of print 13 May 2005. DOI 10.1029/2005GL022552. 
Weningher B, Clare L, Rohling E et al. (2009) The impact of rapid climate change on prehistoric societies during the Holocene in the Eastern Mediterranean. Documenta Praehistorica 36: $7-59$.

Wilkinson R (2011) A multi-proxy study of late Holocene environmental change in the Prokletije Mountains, Montenegro and Albania. PhD Thesis, University of Manchester.

Xoplaki E, González-Rouco JF, Luterbacher J et al. (2004) Wet season Mediterranean precipitation variability: Influence of large-scale dynamics and trends. Climate Dynamics 20: $723-739$.
Xoplaki E, Maheras P and Luterbacher J (2001) Variability of climate in Meridional Balkans during the periods 1675-1715 and 1780-1830 and its impact on human life. Climate Change 48: 581-615.

Zasadni J (2007) The Little Ice Age in the Alps: It's record in glacial deposits and rtick glacier formation. Studia Geomorphologica Carpatho-Balcanica (XLI): 117-137.

Zemp M, Hoelzle M and Haeberli W (2007) Distributed modelling of the regional climate equilibrium line altitude of glaciers in the European Alps. Global and Planetary Change 56: 83-100. 